\title{
VARIATIONS IN CELL WALL ULTRASTRUCTURE AND CHEMISTRY IN CELL TYPES OF EARLYWOOD AND LATEWOOD IN ENGLISH OAK (QUERCUS ROBUR)
}

\author{
Jong Sik Kim and Geoffrey Daniel* \\ Wood Science, Department of Forest Products, Swedish University of Agricultural Sciences, \\ P.O. Box 7008, 75007 Uppsala, Sweden \\ *Corresponding author; e-mail: geoffrey.daniel@slu.se
}

\begin{abstract}
Although there is considerable information on anatomy and gross chemistry of oak wood, little is known on the ultrastructure and chemistry at the individual cell wall level. In particular, differences in ultrastructure and chemistry within the same cell type between earlywood (EW) and latewood (LW) are poorly understood. This study investigated the ultrastructure and chemistry of (vasicentric) tracheids, vessels, (libriform) fibers and axial/ray parenchyma cells of English oak xylem (Quercus robur L.) using light-, fluorescence- and transmission electron microscopy combined with histo/cytochemistry and immunohisto/cytochemistry. EW tracheids showed several differences from LW tracheids including thinner cell walls, wider middle lamella cell corner (MLcc) regions and lesser amounts of mannan epitopes. Fibers showed thicker cell walls and higher amounts of mannan epitopes than tracheids. EW vessels were rich in guaiacyl $(\mathrm{G})$ lignin with a characteristic non-layered cell wall organization (absence of $\mathrm{S}_{1-3}$ layers), whereas LW vessels were rich in syringyl (S) lignin with a three layered cell wall structure $\left(\mathrm{S}_{1-3}\right.$ layers). Formation of a highly lignified and wide protective layer (PL) inside axial/ray parenchyma cells was detected only in EW. Distribution of mannan epitopes varied greatly between cell types and between EW and LW, whereas distribution of xylan epitopes was almost identical in all cell types within a growth ring. Together, this study demonstrates that there are great variations in ultrastructure and chemistry of cell walls within a single growth ring of English oak xylem.
\end{abstract}

Keywords: Libriform fiber, lignin, mannan, parenchyma cell, vasicentric tracheids, vessel, xylan.

\section{INTRODUCTION}

Wood formation results in a variety of cells that have different anatomy and chemistry. Cell types and abundance of each cell type in wood vary greatly between wood species. These variations influence not only different mechanical and biological properties of native woods, but also can accentuate different physical and chemical behaviors during processing between wood species (Green et al. 1999; Taylor et al. 2002; Bodîrlău 
et al. 2007; Santos et al. 2011). Ultimately, these variations influence differences in technological applications of wood between wood species. In this regard, a detailed understanding of wood structure and chemistry is required for a wide range of wood species to achieve a better understanding of natural variations in wood and consequently for its more effective utilization.

Oak is an important hardwood species in Europe and is used for many different applications, such as housing, barrels and furniture (Feuillat et al. 1997; Scotti-Saintagne et al. 2004; Garde-Cerdán \& Ancín-Azpilicueta 2006; Brischke \& Rolf-Kiel 2010). With respect to anatomy, oak represents a ring-porous hardwood with large variations in vessel diameter within a growth ring. In terms of cell types, oak wood is composed of a number of cellular elements including vessels, tracheids, fiber-tracheids, libriform fibers and ray/axial parenchyma cells (Schweingruber 1990; Gričar et al. 2013). The proportion of each cell type in oak wood varies between oak species (Schweingruber 1990; InsideWood 2004-onwards; Wheeler 2011). Even within the same oak species, great variations in cell types and structure occur between earlywood (EW) and latewood (LW) (Schweingruber 1990; Gričar et al. 2013). These variations influence heterogeneity in the physical and chemical behavior of oak wood during processing and consequently the quality of final products (Shchupakivskyy et al. 2014; Hamada et al. 2015). This emphasizes the importance of a detailed understanding of oak wood in relation to variations in chemistry and structure between EW and LW. Although several studies have reported the gross chemistry of oak wood (Pettersen 1984; Fernández de Simón et al. 1996; Bodîrlău et al. 2007), differences in chemistry between EW and LW are poorly understood. Little is also known concerning variations in wall structure between cell types in oak wood at the cellular level. Information on the structure and chemistry at the cellular level should allow for a more detailed interpretation of oak wood in relation to decay patterns, durability and heterogeneity during processing between cell types and between EW and LW. This approach will also help to extend our biological understanding of oak xylem, particularly the relationship between cell function and cell ultrastructure and chemistry.

In this study, we investigated ultrastructural and chemical features of English oak xylem using different microscopy techniques combined with histo/cytochemistry and immunohisto/cytochemistry. Differences in ultrastructure of the cell wall and chemistry of lignin and hemicelluloses between cell types and between EW and LW were mainly examined. Results demonstrate that ultrastructure and chemistry of cell walls in English oak xylem vary greatly between cell types and between EW and LW.

\section{MATERIALS AND METHODS}

\section{Plant materials}

Small wood blocks were removed from a mature English oak tree (Quercus robur L.; c. $20 \mathrm{~cm}$ diameter at breast height) grown in a forest site near the campus of the Swedish University of Agricultural Sciences on September 16, 2014. Small sectors of the second and third growth ring from the cambial zone (sapwood) were cut from wood blocks and fixed with $2 \% \mathrm{v} / \mathrm{v}$ paraformaldehyde $+2.5 \%$ glutaraldehyde in 
$0.05 \mathrm{M}$ sodium cacodylate buffer ( $\mathrm{pH}$ 7.2). Sectors were then embedded in LR White resin (London Resin Co., Basingstoke, UK) by conventional embedding procedures (Kim \& Daniel 2012). Some fresh small blocks were stored in fixative until further use. Developing xylem (i.e. the first growth ring from cambium) was excluded from the experiment.

\section{Light microscopy}

To visualize lignin distribution, transverse sections (c. 30-40 $\mu \mathrm{m})$ prepared from fresh wood blocks were stained according to Wiesner and Mäule reactions (Nakagawa et al.2012). For observations of general anatomy, semi-thin sections (c. $1 \mu \mathrm{m})$ prepared from embedded blocks were stained with toluidine blue. Sections were examined using light microscopy (Leica DMLB, Wetzlar, Germany). Cell wall thickness was measured using micrographic images $(\times 630)$ combined with Image-pro premier software (Media cybernetics, Maryland, USA).

\section{Fluorescence microscopy}

Immunofluorescence labeling was conducted according to procedures described previously (Kim et al. 2012). In brief, semi-thin sections (c. $1 \mu \mathrm{m}$ ) prepared from embedded blocks were incubated in LM5 (1,4- $\beta$-galactan, Jones et al. 1997), LM10 (xylan, McCartney et al .2005) or LM21 (mannan, Marcus et al .2010) monoclonal antibodies (PlantProbes, Leeds, UK), followed by incubation with anti-rat IgG Alexa Fluor 488 (Invitrogen, Oregon, USA). For controls, sections were incubated with antirat IgG Alexa Fluor 488 only. Sections were examined under a fluorescence microscope (Leica DMRE, Wetzlar, Germany) with I3 filter cube (excitation 450-490 nm, emission $>515 \mathrm{~nm})$.

\section{Transmission electron microscopy (TEM)}

For lignin staining, transverse ultrathin sections $(\mathrm{c} .90 \mathrm{~nm})$ prepared from embedded blocks were stained with $\mathrm{KMnO}_{4}$. Immunogold labeling was carried out as described previously (Kim \& Daniel 2012). In brief, ultrathin sections were incubated with either LM5, LM6 (1,5- $\alpha$-arabinan, Willats et al. 1998), LM10/LM11 (xylan, McCartney et al. 2005), LM15 (XXXG motif of xyloglucan, Marcus et al. 2008), LM19/LM20 (homogalacturonan, Verhertbruggen et al. 2009) or LM21 monoclonal antibodies (PlantProbes, Leeds, UK), followed by incubation with secondary antibody labeled with 10-nm colloidal gold particles (BB International, Cardiff, UK). Sections were examined using a Philips CM12 TEM (Philips, Eindhoven, Netherlands) after staining with uranyl acetate.

\section{Classification of cell types}

Classification of cell types into fiber-tracheids and vascular tracheids was avoided in this study. All imperforate cell types that showed formation of bordered pits and surrounded vessels were defined as vasicentric tracheids. The formation of bordered pits and some typical features of vasicentric tracheids including short length and irregular orientation were confirmed using longitudinal sections (not shown). All imperforate 
cell types that did not show distinct bordered pits were described as libriform fibers. EW fibers were classified from LW fibers according to thinner cell walls and location, i.e. near EW vessels including the boundary between EW and LW (EW/LW) (Fig. 2B). Axial parenchyma cells were easily classified from other cell types by presence of starch grains in their lumen. Based on larger lumen diameter in transverse sections, small vessel elements were distinguished from vasicentric tracheids in latewood. With TEM observations, these two cell types were further classified according to distinct differences in cell wall ultrastructure. No notable formation of tyloses was observed in any of the cell types.

\section{RESULTS}

\section{Comparative anatomy and lignin staining between cell types}

Figure 1A-D shows anatomy of English oak xylem after staining with toluidine blue which stains lignified cell walls blue. As reported previously (Schweingruber 1990; Gričar et al. 2013), English oak earlywood (EW) was composed predominantly of vasicentric tracheids (tracheids) and vessels (Fig. 1A, 2), whereas libriform fibers (fibers) were a major cell type in latewood (LW) (Fig. 1D, 2). LW also contained numbers of tracheids, axial parenchyma cells and vessels (Fig. 1B, 2). Overall differences in anatomy and intensity of lignin staining between cell types are summarized in Table 1. EW tracheids (Fig. 1A) showed thinner cell walls and greater numbers of bordered pits than LW tracheids (Fig. 1B). Compared to vessels, tracheid cell walls were thinner in EW and thicker in LW (Fig. 1A, B; Table 1). Axial/ray parenchyma cell walls frequently showed double layers of toluidine blue staining in EW (arrowheads in inset, Fig. 1A), whereas these layers were not observed in LW (Fig. 1B). EW fibers showed slightly thicker cell walls than LW tracheids (Fig. 1C; Table 1). In contrast, LW fibers showed much thicker cell walls than LW tracheids (Fig. 1D; Table 1). Fibers and tracheids associated with axial/ray parenchyma cells had intercellular spaces between them (arrowheads in Fig. 1B-D). However, the frequency of intercellular spaces was

Table 1. Cell wall structure and features of lignin staining in English oak xylem.

Number of ' + ' and ' $*$ ' indicates intensity of staining. Thickness of axial parenchyma cell wall varied greatly even in the same cell depending on cell wall regions.

\begin{tabular}{|c|c|c|c|c|c|c|}
\hline Cell type & & Wall thickness $(\mu \mathrm{m})$ & Wall structure & MLcc regions & Mäule & Wiesner \\
\hline \multirow{2}{*}{$\begin{array}{c}\text { Vasicentric } \\
\text { tracheid }\end{array}$} & EW & $1.4 \pm 0.4(n=50)$ & $\mathrm{S}_{1-3}$ layers & & ++ & $* *$ \\
\hline & LW & $2.4 \pm 0.4(n=50)$ & $\mathrm{S}_{1-3}$ layers & & ++ & $* *$ \\
\hline \multirow{2}{*}{$\begin{array}{l}\text { Libriform } \\
\text { fiber }\end{array}$} & EW & $2.6 \pm 0.5(n=50)$ & $\mathrm{S}_{1-3}$ layers & $\begin{array}{l}\text { - Wider in EW } \\
\text { than in LW }\end{array}$ & ++ & $*$ \\
\hline & LW & $3.9 \pm 0.7(n=50)$ & $\mathrm{S}_{1-3}$ layers & & ++ & $*$ \\
\hline \multirow[t]{2}{*}{ Vessel } & EW & $2.8 \pm 0.6(n=20)$ & Non-layered & $\begin{array}{l}\text { - More frequent } \\
\text { of intercellular }\end{array}$ & + & $* *$ \\
\hline & LW & $1.9 \pm 0.3(n=40)$ & $\mathrm{S}_{1-3}\left(\right.$ thick $\left.\mathrm{S}_{3}\right)$ & $\begin{array}{l}\text { space in fibers } \\
\text { than tracheids }\end{array}$ & ++ & $* *$ \\
\hline \multirow{2}{*}{$\begin{array}{l}\text { Axial } \\
\text { parenchyma }\end{array}$} & EW & $1.7 \pm 0.4(n=50)$ & Non-layered + PL & & +++ & $* *$ \\
\hline & LW & $1.8 \pm 0.5(n=50)$ & Non-layered & & +++ & $* *$ \\
\hline
\end{tabular}

EW = earlywood LW = latewood PL = protective layer MLcc $=$ middle lamella cell corner. 

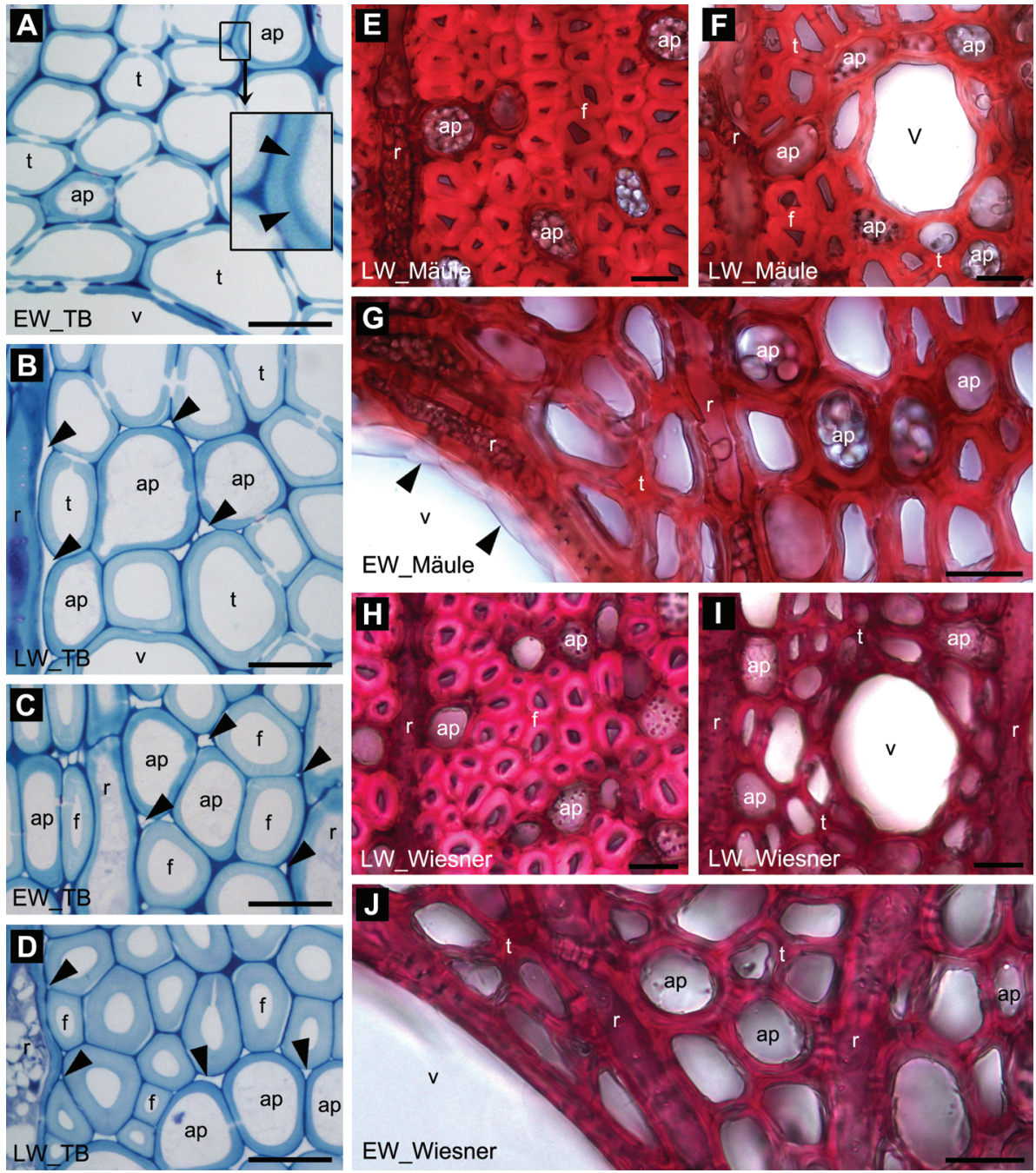

Figure 1. Anatomy and lignin staining of English oak. - A-D: Staining with toluidine blue (TB). Note differences in cell wall anatomy among earlywood (EW) and latewood (LW) including vasicentric tracheids (t), libriform fibers (f), vessels (v) and axial (ap)/ray (r) parenchyma cells; thinner cell wall in EW (A) than in LW (B) tracheids, double layers of TB staining only in axial parenchyma cells of EW (arrowheads, inset A), formation of intercellular spaces between tracheids and fibers associated with axial/ray parenchyma cells (arrowheads in B-D) and much wider middle lamella cell corner (MLcc) regions in EW tracheids (A) than in LW tracheids / fibers (B-D). - E-G: Mäule reaction (syringyl lignin). Note similar staining intensity between LW tracheids and LW fibers $(\mathrm{E}, \mathrm{F})$, stronger reaction in axial/ray parenchyma cells than in tracheids and fibers in EW and LW (E, G), weak reaction in EW vessels (arrowheads in G) and strong reaction in LW vessels $(\mathrm{F})$ similar to LW tracheids / fibers. - H-J: Wiesner reaction (total lignin). Note weaker reaction in fibers than in tracheids, axial/ray parenchyma cells and vessels in EW and LW. - Scale bars $=20 \mu \mathrm{m}$. 
much higher between fibers than between tracheids. The width of the middle lamella cell corner (MLcc) regions of EW tracheids (Fig. 1A) was generally wider than in LW tracheids and fibers (Fig. 1B-D).

With the Mäule reaction, which indicates the presence of syringyl lignin (Iiyama \& Pant 1988), no notable difference was detected between fibers and tracheids (Fig. 1E-G; Table 1). Axial/ray parenchyma cells showed an overall stronger reaction than fibers and tracheids in both EW and LW (Fig. 1E, G; Table 1). The only exception was axial parenchyma cells near LW vessels which showed similar staining intensity to
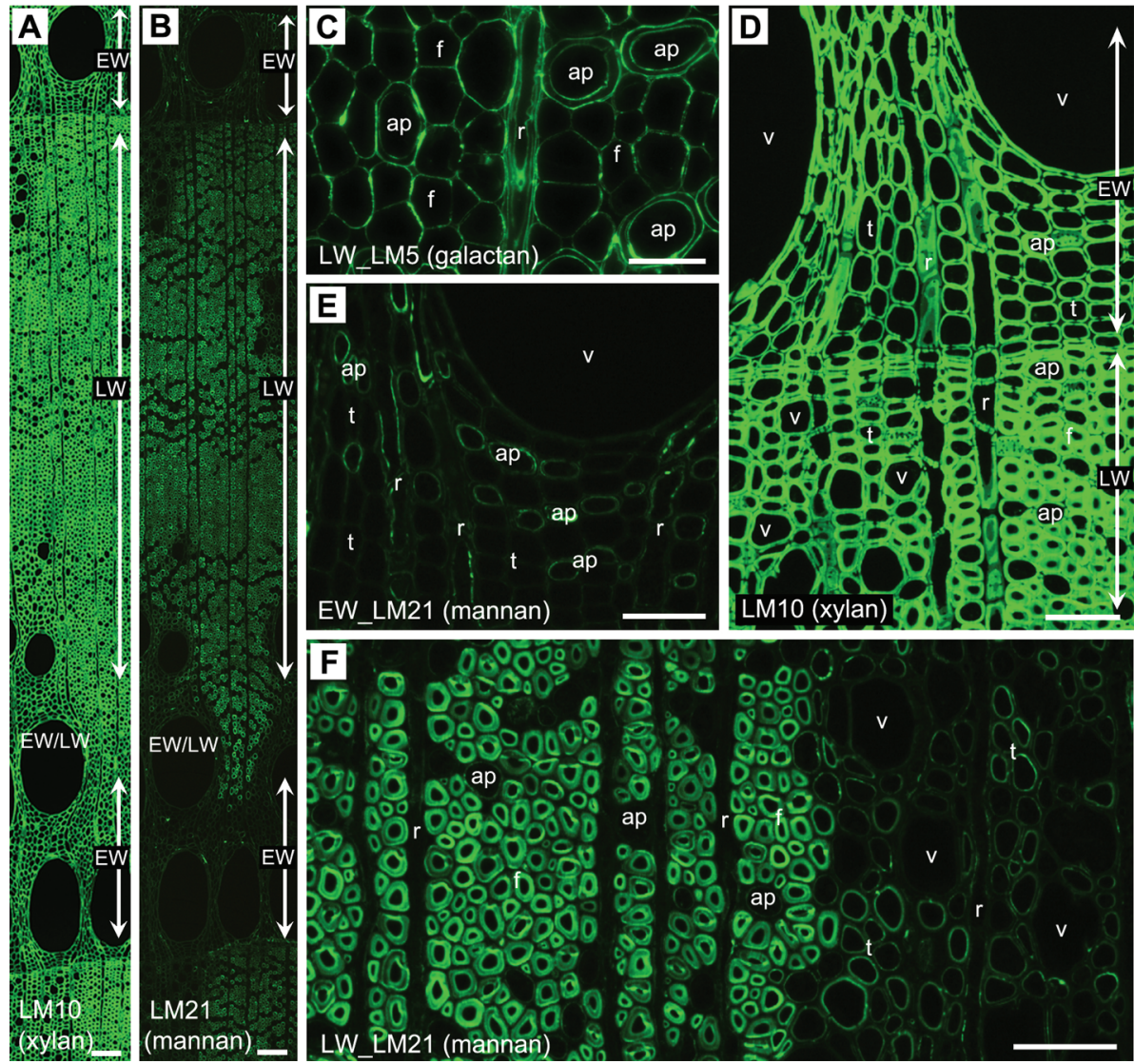

Figure 2. Immunofluorescence labeling of LM5 (C), LM10 (A, D), and LM21 (B, E, F) epitopes in English oak. -A \& D: LM10 (xylan) labeling showing no notable difference in intensity within a growth ring between cell types. - B, E \& F: LM21 (mannan) labeling showing much weaker intensity in earlywood (EW) than in latewood (LW) including boundary EW/LW. Note variations in the intensity of labeling between cell types; strongest in libriform fibers (f) and weakest in EW vasicentric tracheids (t) / LW vessels (v)/parenchyma cells (axial/ray) (ap/r). - C: Positive and negative LM5 (galactan) labeling in compound middle lamellae and secondary cell walls of fibers respectively, indicating absence of tension wood. Note strong labeling in the innermost layer of axial/ray parenchyma cells. - Scale bars $=100 \mu \mathrm{m}(\mathrm{A}, \mathrm{B}), 25 \mu \mathrm{m}(\mathrm{C}), 50 \mu \mathrm{m}(\mathrm{D}-\mathrm{F})$. 
LW tracheids and fibers (Fig. 1F). In vessels, LW vessels showed a strong reaction similar to tracheids and fibers (Fig. 1F; Table 1), whereas EW vessels showed a very weak reaction (arrowheads in Fig. 1G). Concerning the Wiesner reaction, indicating total lignin (Pomar et al. 2002), tracheids, axial/ray parenchyma cells and vessels showed an almost identical reaction intensity in EW and LW (Fig. 1H-J) which was stronger than that in fibers (Fig. 1H; Table 1).

\section{Immunofluoresence detection of xylan and mannan epitopes}

Since distribution patterns of mannan epitopes in tension wood differ significantly from normal wood (Kim \& Daniel 2012), immunofluorescence labeling of LM5 epitopes (galactan) was carried out to examine whether or not tension wood was present in the samples used. LM5 epitope has been frequently used to determine presence of tension wood, i.e. gelatinous fibers of tension wood showed LM5 epitopes in their secondary cell walls as well as compound middle lamella (CML) regions (Arend 2008). Figure 2C shows immunofluorescence labeling of LM5 epitopes in LW fibers and axial parenchyma cells. Labeling was detected only in CML regions of fibers, indicating absence of tension wood. Immunofluorescence labeling of hemicellulose epitopes was carried out using serial sections. No non-specific binding of secondary antibody (Alexa Fluor 488) was detected in control samples where the primary antibody was omitted (not shown). Lignin autofluorescence was completely eliminated in the captured images by using a short exposure time.

Abundant LM10 epitopes (xylan) were detected across growth rings with similar levels for both EW and LW (Fig. 2A, D). Also no notable difference in intensity of LM10 labeling was detected between cell types including fibers, tracheids and ray/axial parenchyma cells (Fig. 2D). In contrast, LM21 (mannan) showed stronger intensity of labeling in LW than EW within a growth ring (Fig. 2B). Labeling intensity also varied between cell types. LM21 showed strongest labeling intensity in LW fibers and weakest in EW tracheids and EW/LW vessels (Fig. 2E, F). Variations in labeling intensity of LM21 were also detected between LW tracheids (Fig. 2F).

\section{Ultrastructure of cell walls}

The differences in cell wall ultrastructure between cell types are summarized in Table 1. Figure 3A-C shows EW cells after staining with $\mathrm{KMnO}_{4}$ for lignin. EW tracheids showed typical secondary cell wall structure (i.e. $\mathrm{S}_{1-3}$ layers) (Fig. 3A; Table 1) with large bordered pits (arrowheads in inset of Fig. 3A). In contrast, EW vessels showed a non-layered cell wall organization (i.e. absence of $\mathrm{S}_{1-3}$ structure) (Fig. 3C; Table 1). Wart-like structures were also detected in a few vessels (arrowheads in right inset, Fig. 3C). EW axial/ray parenchyma cells showed a non-layered cell wall organization and development of wide protective layers (Meyer \& Côté 1968; Chafe 1974; Murmanis 1975) inside their cell walls (Fig. 3B, C and left inset). Narrow layers with strong electron density similar to $\mathrm{CML}$ regions were also detected between parenchyma cell walls and protective layers (asterisks in Fig. 3C and left inset). These layers (arrowheads) showed an abundance of LM6 (arabinan, Fig. 3D), LM15 (xyloglucan, Fig. 3E) and LM21 (mannan, Fig. 3F) epitopes (Table 2). Very sparse LM5 


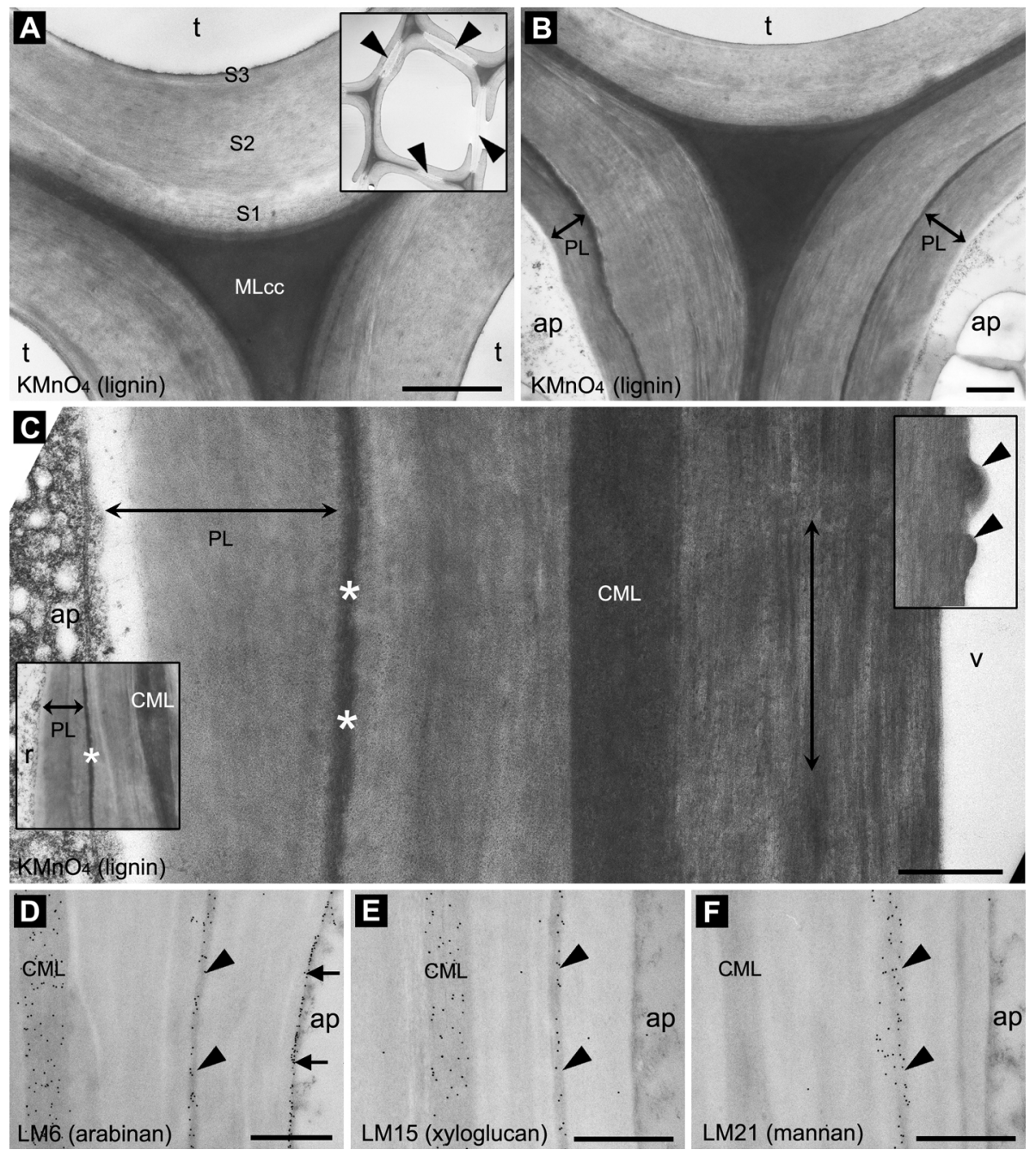

Figure 3. English oak earlywood after staining with $\mathrm{KMnO}_{4}$ and labeling with $\mathrm{LM} 6, \mathrm{LM} 15$ and LM21 epitopes. - A: Vasicentric tracheids ( $\mathrm{t}$ ) showing the typical three layers of secondary cell wall structure $\left(\mathrm{S}_{1-3}\right.$ layers) with bordered pits in radial and tangential orientations (arrowheads in inset) . MLcc = middle lamella cell corner. - B: Axial parenchyma cells (ap) showing a nonlayered cell wall organization and formation of protective layers (PL) inside their cell walls. C-F: Vessels (v) showing a non-layered cell wall organization (C) and formation of wart-like structure (arrowheads, right inset C). Note the compound middle lamellae (CML) like electron dense layer (asterisks in C and left inset) between axial/ray (r) parenchyma cell wall and PL with abundance of LM6 (arabinan), LM15 (xyloglucan) and LM21 (mannan) epitopes (arrowheads in D-F, respectively). Note also abundant LM6 epitopes in the innermost layer of axial parenchyma cell wall (arrowheads in D). - Scale bars $=1 \mu \mathrm{m}(\mathrm{A}, \mathrm{B}), 500 \mathrm{~nm}(\mathrm{C}-\mathrm{F})$. 
(galactan) epitopes were also detected in these layers (not shown). These features of labeling were similar to CML regions that showed presence of LM5, LM6, LM15 and LM21 epitopes with high variations in amounts of LM5 and LM21 epitopes between cells, including their absence (Fig. 2C, 3D-F, 7B). In contrast, homogalacturonan (HG, LM19/LM20) and xylan (LM10/LM11) epitopes were not detected in these electron dense layers (not shown). These features differed from CML regions that showed presence of LM19/LM20 epitopes even though they showed high variations in amounts

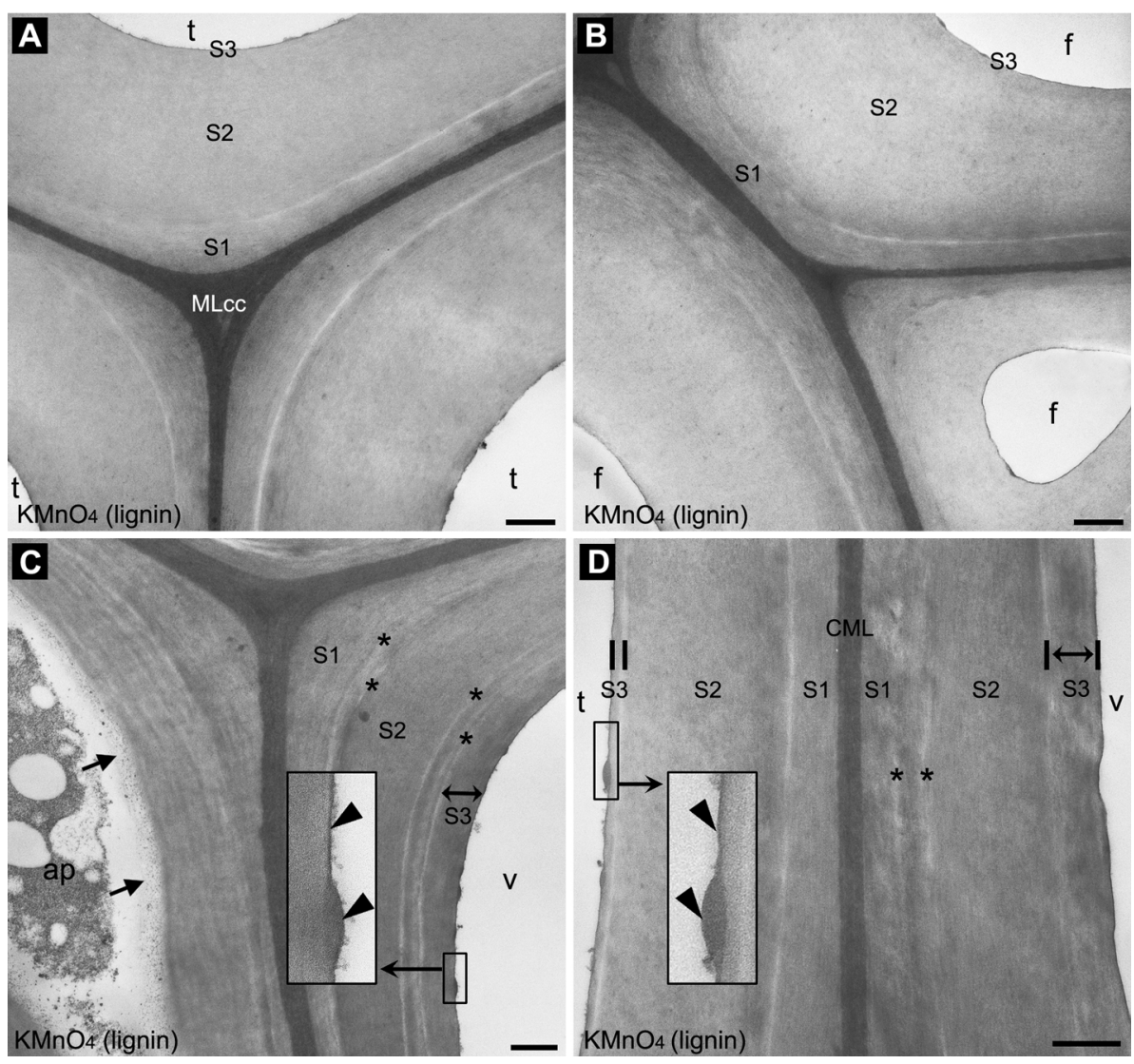

Figure 4. English oak latewood after staining with $\mathrm{KMnO}_{4}$. - A \& B: Vasicentric tracheids (t) and libriform fibers (f). Note the similar cell wall organization between both cell types and the much narrower width of the middle lamella cell corner (MLcc) regions compared to earlywood (EW) tracheids (Fig. 3A). - C: Axial parenchyma cells (ap) and vessels (v) showing a non-layered cell wall organization and three-layered cell wall structure, respectively. Note the absence of a protective layer inside axial parenchyma cell walls (arrows) (i.e. differ from EW, Fig. 3B, C) and formation of warts and warty layers in vessels (arrowheads in inset). $-\mathrm{D}$ : Difference in thickness of the $\mathrm{S}_{3}$ layer between tracheids and vessels, being much wider in vessels than in tracheids. Note some extra layers at the boundary of $\mathrm{S}_{1} / \mathrm{S}_{2}$ or $\mathrm{S}_{2} / \mathrm{S}_{3}$ in vessels (asterisks in C, D), and formation of warts and warty layers in tracheids (arrowheads in inset). - Scale bars $=500 \mathrm{~nm}$. 
between cells (not shown). In addition, abundant LM5 (not shown) and LM6 (arrows in Fig. 3D) epitopes were detected in the innermost layer of axial/ray parenchyma cells (the interface between cell wall and lumen) in both EW and LW as shown with fluorescence labeling of LM5 epitopes (Fig. 2C).

Like EW tracheids, LW tracheids showed a typical secondary cell wall structure (i.e. $\mathrm{S}_{1-3}$ layers) (Fig. 4A; Table 1). Ultrastructure of fiber cell wall including EW (not shown) and LW (Fig. 4B) was also almost identical to tracheids (i.e. $\mathrm{S}_{1-3}$ layers) (Table 1). Unlike EW vessels (non-layered cell wall, Fig. 3C), LW vessels showed an overall similar cell wall organization (i.e. $\mathrm{S}_{1-3}$ layers) as LW tracheids (Fig. 4C, D; Table 1). The exception was the presence of some extra layers in the boundary $S_{1} / S_{2}$ or $S_{2} / S_{3}$ of some vessels (asterisks in Fig. 4C, D) and a wider $S_{3}$ layer in vessels than in tracheids (Fig. 4C, D). Warts and warty layer-like structures were detected in some tracheids and vessels of LW (arrowheads in insets of Fig. 4C, D). These structures were more frequent in vessels than tracheids. No warts and warty layer-like structures were detected in fibers. Like EW (Fig. 3C), LW axial/ray parenchyma cells showed a non-layered cell wall organization (Fig. 4C; Table 1). However, the formation of strongly lignified protective layers in EW (Fig. 3B, C) was not detected in LW axial/ray parenchyma cells (Fig. 4C). Only non- or very weakly lignified protective layer-like amorphous layers were detected in LW axial/ray parenchyma cells (arrows in Fig. 4C). As outlined with light microscopy observations (Fig. 1A-D), the width of MLcc regions was narrower in LW than in EW, irrespective of cell type (Fig. 3A, B vs. Fig. 4A-C). Formation of intercellular spaces was also frequently observed in MLcc regions of LW tracheids and fibers in association with axial/ray parenchyma cells (Fig. 5A). MLcc regions of some LW fibers also showed formation of electron lucent regions (i.e. less lignified regions) (asterisk in Fig. 5B). These regions were localized only by xylan epitopes (LM10/LM11) (asterisk in Fig. 5G, H). No pectin, xyloglucan or mannan epitopes were detected in these regions (asterisk in Fig. 5C-F) (Table 2). Similar regions were very rarely detected in tracheids (not shown).

Table 2. Distribution of pectin and hemicellulose epitopes in English oak xylem.

Number of ' + ' and ' $*$ ' indicates intensity of labeling.

\begin{tabular}{|c|c|c|c|c|c|}
\hline \multirow{2}{*}{ Cell type } & & \multicolumn{2}{|c|}{ Secondary cell wall } & \multirow{2}{*}{$\begin{array}{l}\text { Electron lucent regions } \\
\text { (MLcc of libriform fiber) }\end{array}$} & \multirow{2}{*}{$\begin{array}{l}\text { Electron dense layer } \\
\text { (PL/Parenchyma wall) }\end{array}$} \\
\hline & & Xylan & Mannan & & \\
\hline \multirow{2}{*}{$\begin{array}{l}\text { Vasicentric } \\
\text { tracheid }\end{array}$} & EW & +++ & $*$ & & \\
\hline & LW & +++ & $* *$ & $\begin{array}{l}\text { - Absence of pectin, } \\
\text { xyloglucan and mannan }\end{array}$ & $\begin{array}{l}\text { - Presence of arabinan, } \\
\text { xyloglucan and mannan }\end{array}$ \\
\hline \multirow{2}{*}{$\begin{array}{l}\text { Libriform } \\
\text { fiber }\end{array}$} & EW & +++ & $* * *$ & epitopes & epitopes \\
\hline & LW & +++ & $* * *$ & & \\
\hline \multirow[t]{2}{*}{ Vessel } & EW & +++ & $*$ & $\begin{array}{l}\text { - Presence of xylan } \\
\text { epitopes }\end{array}$ & $\begin{array}{l}\text { - Absence of } \\
\text { homogalacturonan }\end{array}$ \\
\hline & LW & +++ & $*$ & & $\begin{array}{l}\text { (HG) and xylan } \\
\text { epitopes }\end{array}$ \\
\hline \multirow{2}{*}{$\begin{array}{l}\text { Axial/ray } \\
\text { parenchyma }\end{array}$} & EW & +++ & $*$ & & \\
\hline & LW & +++ & $*$ & & \\
\hline
\end{tabular}

$\mathrm{EW}=$ earlywood $; \mathrm{LW}=$ latewood PL = protective layer; $\mathrm{MLcc}=$ middle lamella cell corner. 


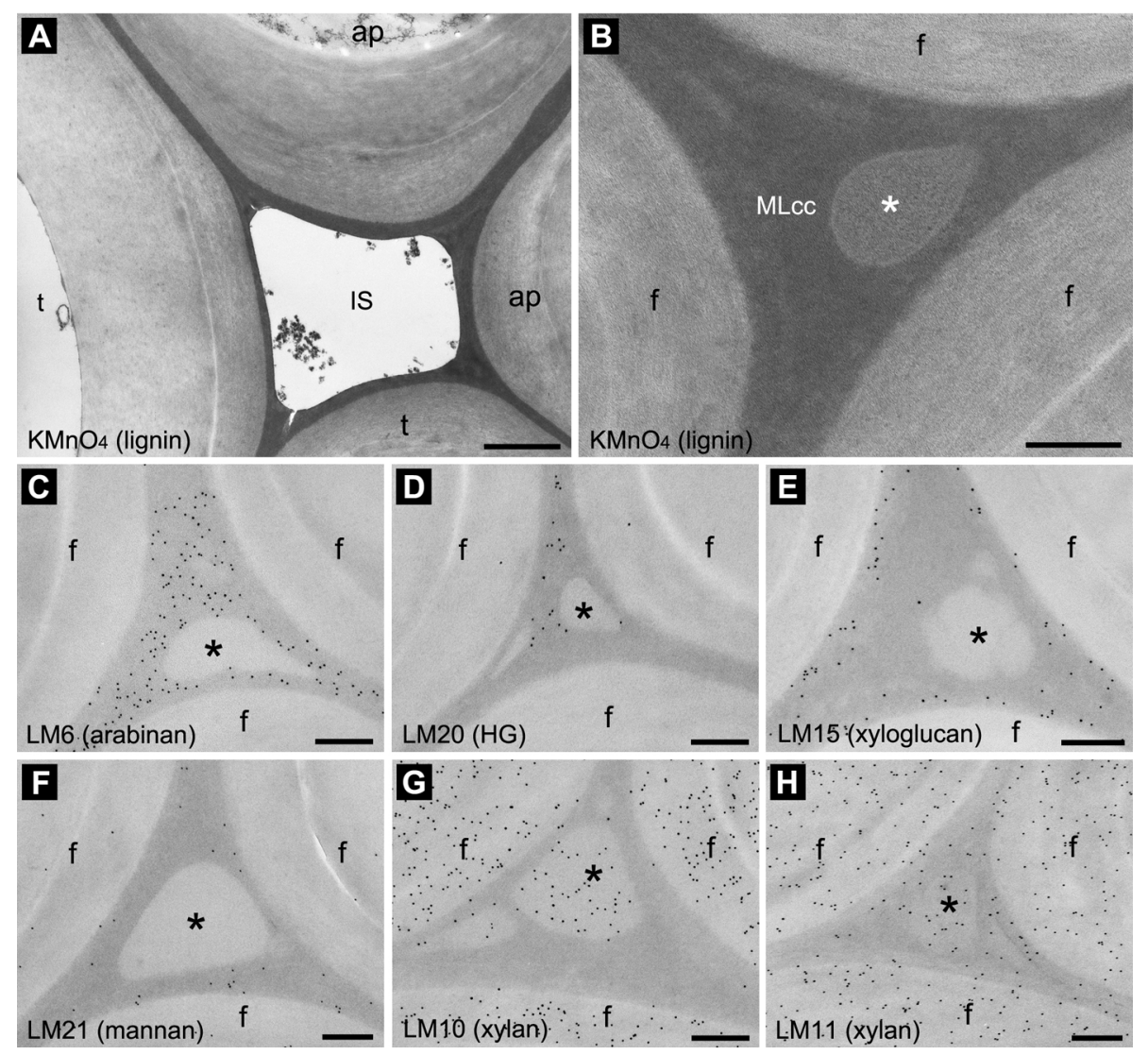

Figure 5. Formation of intercellular spaces and electron lucent regions in middle lamella cell corner (MLcc) regions of English oak latewood. - A \& B: Staining with $\mathrm{KMnO}_{4}$. A: Intercellular space (IS) between vasicentric tracheids ( $t$ ) and axial parenchyma cells (ap). - B-H: Electron lucent regions (asterisk) in MLcc regions of libriform fibers (f) showing weaker intensity of $\mathrm{KMnO}_{4}$ staining than in other MLcc regions (B). Note the labeling by LM10 and LM11 antibodies (xylan; G, H) and absence of LM6 (arabinan, C), LM 20 (homogalacturonan, D), LM15 (xyloglucan, E) and LM21 (mannan, F) epitopes in electron lucent regions (asterisks). - Scale bars $=1 \mu \mathrm{m}(\mathrm{A}), 250 \mathrm{~nm}(\mathrm{~B}-\mathrm{H})$.

\section{Immunogold localization of xylan and mannan epitopes in secondary cell walls}

Immunofluorescence observations (Fig. 2) were further advanced by immunogold labeling. No non-specific binding of secondary antibody (gold particles) was detected in control samples where the primary antibody was omitted (not shown). Overall distributional patterns of pectin and hemicellulose epitopes are shown in Table 2. No specific labeling of pectin and xyloglucan epitopes was present in secondary cell walls except for CML-like electron dense layers detected between parenchyma cell walls and protective layers (PL/parenchyma wall, Table 2; asterisks in Fig. 3C).

Abundant xylan epitopes were detected across the cell wall, irrespective of cell type in EW and LW (Fig. 6). In contrast, mannan epitopes showed great distributional 


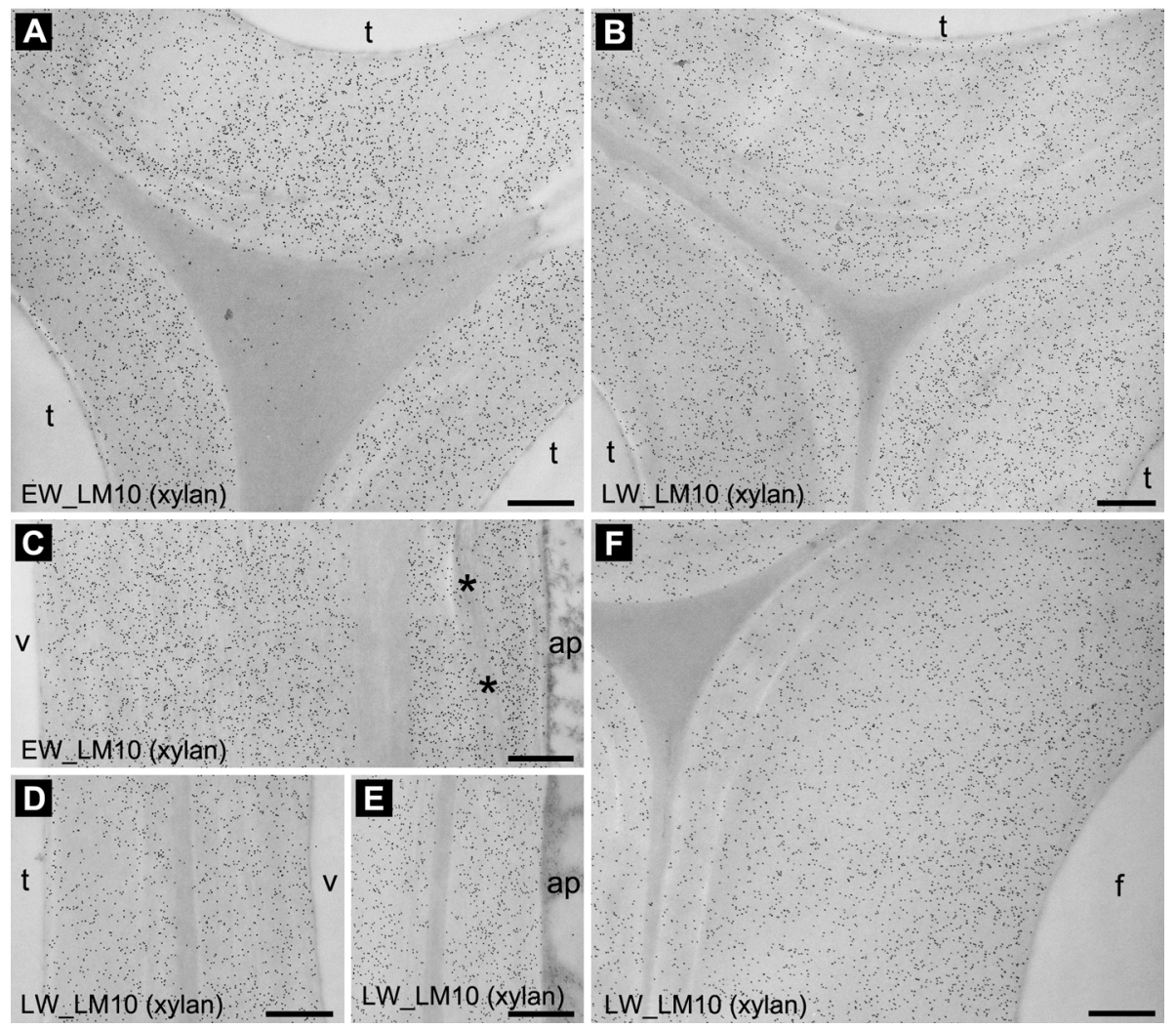

Figure 6. Immunogold labeling of LM10 (xylan) epitopes in English oak. (A, C) Earlywood (EW) and (B, D-F) Latewood (LW). Note the similarity in distribution patterns of epitopes between cell types including vasicentric tracheids ( $\mathrm{t}$; A, B), vessels (v; C, D), axial parenchyma cells (ap; $\mathrm{C}, \mathrm{E}$ ) and libriform fibers (f; F). Asterisks in $\mathrm{C}$ indicate an electron dense layer between the axial parenchyma cell wall and the protective layer (PL) (Fig. 3C). - Scale bars $=500 \mathrm{~nm}$.

variations between cell types and between EW and LW. EW tracheids (Fig. 7A) showed lower amounts of mannan epitopes in the cell wall compared to LW tracheids (Fig. 7B). Most mannan epitopes were detected in the inner cell wall regions of LW tracheids with high variations in amounts between tracheids (Fig. 7B). Fibers showed higher amounts of mannan epitopes than LW tracheids with similar patterns of distribution (i.e. more pronounced epitopes towards cell lumen, Fig. 7C). No notable differences in mannan distribution were detected between EW and LW fibers. EW vessels showed sparse mannan epitopes in the cell wall with slightly higher amounts than EW tracheids (Fig. 7A). Mannan epitopes were very sparse in LW vessels (Fig. 7D). Axial parenchyma cell walls of EW and LW showed very sparse mannan epitopes (Fig. 3F, 7E) even though abundant mannan epitopes were detected in the interface layer between axial parenchyma cell walls and protective layers in EW (Fig. 3F). Ray parenchyma cells showed similar distribution patterns of mannan epitopes to axial parenchyma cells (not shown). 


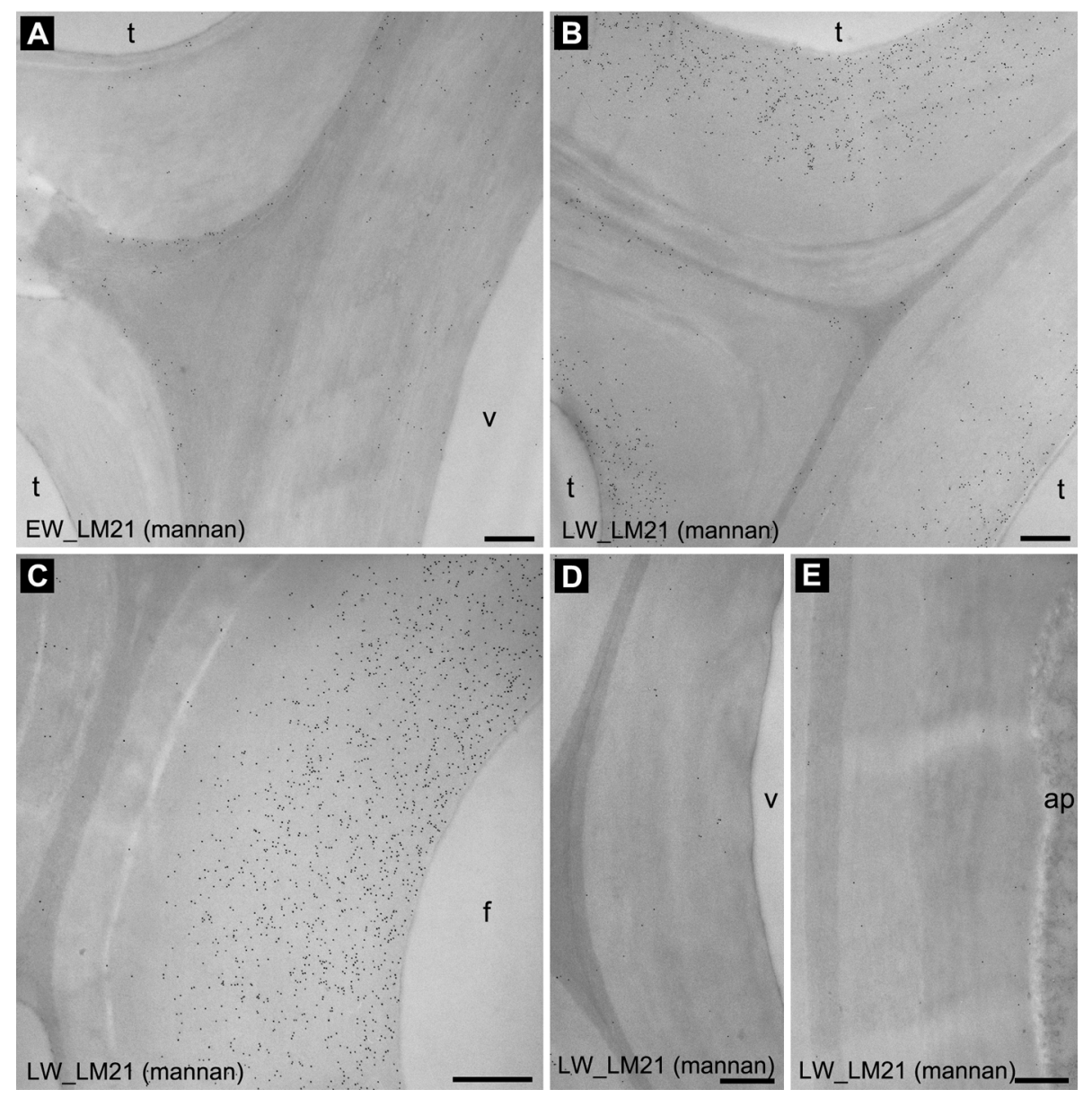

Figure 7. Immunogold labeling of LM21 (mannan) epitopes in English oak. - A: Earlywood $(\mathrm{EW})$ vasicentric tracheids $(\mathrm{t})$ and vessels $(\mathrm{v})$ showing sparse mannan epitopes in cell walls. $-\mathrm{B}$ : Latewood (LW) tracheids showing some strong epitopes in cell walls with variations in amounts of epitopes between tracheids. - C: LW libriform fibers (f) showing the greater abundance of epitopes than in tracheids (A, B). - D \& E: LW vessels and LW axial parenchyma cells (ap) showing sparse epitopes in cell walls. - Scale bars $=500 \mathrm{~nm}$.

\section{DISCUSSION}

Although there is considerable information on the anatomy and gross chemistry of oak wood, little is known about the ultrastructure and chemistry at the individual cell wall level. Also the natural variations in ultrastructure and chemistry between cell types and between EW and LW in oak wood are very poorly understood. This study highlights that ultrastructure and chemistry of cell walls in English oak wood vary greatly between cell types and between EW and LW. With immunolocalization (Fig. 2, 6, 7), it is important to note that this study did not consider masking effects of epitopes between cell wall 
components. Some previous studies showed severe masking effects of HG in primary cell walls of annual plants on detection of xyloglucan and mannan epitopes (Marcus et al. 2008; Marcus et al.2010). In contrast, these masking effects of HG in primary cell walls of normal and compression wood were not obvious (Donaldson \& Knox 2012). In addition, potential effects of lignin on detection of mannan and xylan epitopes were not pronounced in secondary cell walls of wood cells (Kim et al. 2011; Donaldson \& Knox 2012). However, the possibility of masking effects between cell wall components, particularly lignin (in secondary cell walls and CML) and HG (in primary cell walls and CML) on detection of epitopes is not completely ruled out in the study.

\section{Vasicentric tracheids}

Tracheids were a major cell type in the EW of English oak xylem examined. Some tracheids also occurred in LW. Cell wall organization $\left(\mathrm{S}_{1-3}\right.$ layers) was almost identical between EW and LW tracheids except for differences in cell wall thickness (Table 1). However, EW tracheids showed wider MLcc regions than LW tracheids. Although the reason for this difference between EW and LW tracheids is unclear in this study, it can be considered that the difference observed may influence the total lignin content, i.e. ratio of middle lamellae including MLcc regions (i.e. areas showing the highest lignin content in wood, g/g) to secondary cell walls is higher in EW tracheids than in LW tracheids, thereby resulting in higher lignin content in EW than in LW tracheids. Regarding chemistry, no notable differences in lignin staining intensity and types (i.e. S/G ratio) were detected in EW and LW tracheids (Table 1). Both EW and LW tracheids contained certain levels of S-lignin in the cell wall. In contrast, differences in distribution of mannan epitopes were obvious between EW and LW tracheids (Table 2). Consequently, this study suggests that there are some differences in structure and chemistry between EW and LW tracheids in English oak.

\section{Libriform fibers}

Fibers in English oak were mostly developed in LW but some fibers were also observed in EW. Ultrastructure and chemistry of fiber cell walls were almost identical between EW and LW (Table $1 \& 2$ ). Compared to tracheids, the cell wall organization of fibers $\left(\mathrm{S}_{1-3}\right.$ layers) was almost identical. However, fibers showed several differences in ultrastructure from tracheids, including thicker cell walls than tracheids, absence of warts, and narrower width of MLcc regions than EW tracheids (Table 1). Concerning lignin staining, fibers showed lower total lignin content (i.e. weaker intensity of the Wiesner reaction) than tracheids but similar levels of S-lignin to tracheids, indicating higher $\mathrm{S} / \mathrm{G}$ ratio in fibers than in tracheids (Table 1). With hemicelluloses, immunocytochemical labeling revealed the distribution of mannan epitopes in fibers to differ from tracheids, particularly in EW (Table 2). Fibers showed stronger labeling intensity of mannan epitopes than tracheids. This may indicate that mannan content is lower in tracheids than in fibers. With more abundant mannan epitopes in fibers than in vessels and parenchyma cells, we may assume that mannan may also play an important role in mechanical support cells (i.e. fibers). The lack of a notable difference in xylan epitopes between fibers and other cell types may also support this hypothesis. Similar 
results were also observed in a previous study of European aspen which showed lower amounts of mannan epitopes in vessels and ray parenchyma cells than in fibers (Kim \& Daniel 2012).

Since tracheids/vessels and fibers are major cell types in EW and LW of English oak respectively, results indicate that EW contains lower amounts of mannan than LW within a growth ring of English oak xylem. In addition, results demonstrate that xylan is a major non-cellulosic polysaccharide in electron lucent regions of fiber MLcc regions (Fig. 5; Table 2).

Regarding distribution patterns of xylan epitopes, LM10 and LM11 labeling were evenly distributed across fiber cell walls. These results differ from previous studies in other hardwood species. LM10 showed a stronger labeling in the outer than the inner fiber cell wall in hybrid aspen, European aspen and ash (Kim \& Daniel 2012; Kim et al. 2012, 2015), whereas LM11 showed an even distribution across fiber cell walls in these species. On the basis of binding properties of LM10 (unsubstituted/low substituted xylans) and LM11 (low and high substituted xylans) antibodies (McCartney et al. 2005), we can expect that English oak fibers may be composed of a more homogeneous distribution of xylans than fibers in hybrid aspen, European aspen and ash. It can also be assumed that differences in patterns of lignification in fiber cell walls (i.e . different lignin content between cell wall layers) between wood species may induce differences in distribution of xylan epitopes between wood species. Donaldson and Knox (2012) proposed that there are relationships between lignification and distribution of hemicelluloses in radiata pine. This aspect was also observed in distribution of mannan epitopes. Lower lignification in fibers than in tracheids was likely to be related to higher amounts of mannan epitopes in fibers than in tracheids. However, this correlation was unclear in tracheids.

Differences in distribution of mannan epitopes were obvious between EW and LW tracheids, even though EW and LW tracheids showed similar features of lignin staining. Any specific differences in distribution of xylan epitopes were also detected even though differences in lignification were pronounced between fibers and other cell types in this study. Further studies on lignin distribution using more specific and quantitative methods, such as fluorescence microscopy combined with lignin autofluorescence, UV microscopy and immunohisto/cytochemisty using antibodies (Musha \& Goring 1975; Donaldson 2001, 2012; Joseleau et al. 2004; Kiyoto et al. 2013) will provide clearer evidence of a correlation in distribution between hemicelluloses and lignin in English oak xylem cells.

\section{Vessel elements}

Results demonstrate that vessels in English oak xylem not only have a different vessel diameter but also a different ultrastructure and lignin chemistry between EW and LW (Table 1). EW vessels showed a non-layered cell wall organization with low amounts of S-lignin, whereas LW vessels revealed generally three layers of secondary cell wall structure $\left(\mathrm{S}_{1-3}\right.$ layers) rich in $\mathrm{S}$-lignin. At the same time, this result indicates that EW vessels are rich in G-lignin since EW and LW vessels showed similar intensity of lignin staining for total lignin content. This is consistent with the conclusion that 
the S/G ratio in vessels varies in ring-porous hardwoods (Donaldson 2001). Water transport in oak is performed mainly by EW vessels (Gričar et al. 2013), suggesting that differences in cell wall structure and lignin type between EW and LW vessels may be closely related to different contributions of EW and LW vessels to water transport in English oak. At present, we hypothesize that the non-layered cell wall organization and high concentration of G-lignin in EW vessels may allow tighter sealing of cell walls to prevent water leakage than in LW vessels. In contrast to cell wall ultrastructure and lignin chemistry, distribution of hemicellulose epitopes was almost identical between EW and LW vessel cell walls (Table 2). Vessels showed sparse and abundant mannan and xylan epitopes, respectively. Compared to fibers (i.e. mechanical supporting cells), labeling intensity was almost identical for xylan epitopes but lower for mannan epitopes in vessels (i.e. water conducting cells). These results may indicate that type and concentration of hemicellulose may not be closely related to the water conducting function in English oak xylem. This differs from an early study of Yoshinaga et al. (1993) who proposed that xylan has a close relationship to the water conducting function as well as G-lignin based on neutral sugar analysis of various fractions obtained from Japanese oak (Quercus mongolica Fischer var. grosseserrata Rehd. \& Wils.).

\section{Parenchyma cells}

Results show that the ultrastructure of (axial/ray) parenchyma cell walls in relation to the presence of a protective layer differs between EW and LW in English oak (Table 1). EW showed a highly lignified wide protective layer inside parenchyma cell walls, whereas a protective layer was unclear in LW. Several earlier studies also reported a protective layer inside parenchyma cell walls in several hardwood species and proposed that these layers participate in the formation of tyloses within the vessel lumen (Meyer \& Côté 1968; Chafe 1974; Murmanis 1975; Rioux et al. 1998; Clérivet et al. 2000; De Micco et al. 2016). This suggests that ultrastructural differences in parenchyma cells between EW and LW in relation to the formation of a protective layer may be related to differences in the formation of tyloses between EW and LW vessels. Formation of tyloses in English oak xylem is common in EW vessels but is relatively rare in LW vessels (Cochard \& Tyree 1990).

Regarding lignin chemistry, parenchyma cell walls showed overall higher S-lignin content than fibers, tracheids and vessels, irrespective of EW and LW (Table 1). With hemicelluloses, parenchyma cell walls were rich in xylan but were sparse in mannan epitopes in both EW and LW (Table 1). Similar results were also observed in ray parenchyma cells of European aspen (diffuse-porous hardwood) (Kim \& Daniel 2012). With respect to protective layers, chemistry was similar to parenchyma cell walls. Apart from CML-like electron dense layers between parenchyma cell walls and protective layers that showed abundant arabinan, xyloglucan and mannan epitopes (Fig. 3D-F), no pectin and xyloglucan epitopes were detected in protective layers. This differs from the results of Rioux et al. (1998), who reported the presence of pectin epitopes across protective layers of several hardwood species. At present, it appears that the protective layer shows a different chemistry dependent on the species. 


\section{CONCLUSIONS}

This study demonstrates that the ultrastructure and chemistry of the cell wall in English oak vary greatly between cell types and between EW and LW. Even within the same cell type, the ultrastructure and chemistry of the cell wall varied between EW and LW. Results also indicate that distribution patterns of mannan are more cell specific than xylan in English oak. Altogether, this study extends our understanding of the natural heterogeneity of structure and chemistry in English oak. Results may allow for a more detailed interpretation in biological and industrial applications and also extend our basic understanding of different biological functions of cells in relation to cell wall structure and chemistry.

\section{ACKNOWLEDGEMENTS}

The authors gratefully acknowledge funding provided by Formas projects 2008-1399, 2009-582, and 2011-416.

\section{REFERENCES}

Arend M. 2008. Immunolocalization of (1,4)- $\beta$-galactan in tension wood fibers of poplar. Tree Physiol. 28: 1263-1267.

Bodîrlău R, Spiridon I \& Teacă CA. 2007. Chemical investigation of wood tree species in temperate forest in east-northern Romania. BioResources 2: 41-57.

Brischke C \& Rolf-Kiel H. 2010. Durability of European oak (Quercus spp.) in ground contact - a case study on fence posts in service. Eur. J. Wood Prod. 68: 129-137.

Chafe SC. 1974. Cell wall formation and "protective layer" development in the xylem parenchyma of trembling aspen. Protoplasma 80: 335-354.

Clérivet A, Déon V, Alami I, Lopez F, Geiger J-P \& Nicole M. 2000. Tyloses and gels associated with cellulose accumulation in vessels are responses of plane tree seedlings (Platanus $\times$ acerifolia) to vascular fungus Ceratocystis fimbriata $\mathrm{f}$. sp. platani. Trees 15: 25-31.

Cochard H \& Tyree MT. 1990. Xylem dysfunction in Quercus: vessel sizes, tyloses, cavitation and seasonal changes in embolism. Tree Physiol. 6: 393-407.

De Micco V, Balzano A, Wheeler EA \& Baas P. 2016. Tyloses and gums: a review of structure, function and occurrence of vessel occlusions. IAWA J. 37: 186-205.

Donaldson LA. 2001. Lignification and lignin topochemistry - an ultrastructural view. Phytochemistry 57 : 859-873.

Donaldson LA \& Knox JP. 2012. Localization of cell wall polysaccharides in normal and compression wood of radiata pine: relationships with lignification and microfibril orientation. Plant Physiol. 158: 642-653.

Fernández de Simón B, Cadahía E, Conde E \& García-Vallejo MC. 1996. Low molecular weight phenolic compounds in Spanish oak woods. J. Agric. Food Chem. 44: 1507-1511.

Feuillat F, Dupouey J-L, Sciama D \& Keller R. 1997. A new attempt at discrimination between Quercus petraea and Quercus robur based on wood anatomy. Can. J. Forest Res. 27: 343-351.

Garde-Cerdán T \& Ancín-Azpilicueta C. 2006. Review of quality factors on wine ageing in oak barrels. Trends Food Sci. Technol. 17: 438-447.

Green DW, Winandy JD \& Kretschmann DE. 1999. Mechanical properties of wood. In: Forest Products Laboratory (ed.), Wood handbook - Wood as an engineering material (General technical report FPL-GTR-113): 4.1-4.45. U.S. Department of Agriculture, Madison. 
Gričar J, De Luis M, Hafner P \& Levanič T. 2013. Anatomical characteristics and hydrologic signals in tree-rings of oaks (Quercus robur L.). Trees 27: 1669-1680.

Hamada J, Pétrissans A, Mothe F, Ruelle J, Pétrissans M \& Gérardin P. 2015. Variations in the natural density of European oak wood affect thermal degradation during thermal modification. Ann. For. Sci. 73: 277-286.

Iiyama K \& Pant R. 1988. The mechanism of the Mäule colour reaction: introduction of methylated syringyl nuclei into softwood lignin. Wood Sci. Technol. 22: 167-175.

InsideWood. 2004-onwards. Published on the internet (http://insidewood.lib.ncsu.edu/search).

Jones L, Seymour GB \& Knox JP. 1997. Localization of pectic galactan in tomato cell walls using a monoclonal antibody specific to $(1 \rightarrow 4)-\beta$-D-galactan. Plant Physiol. 113: 1405-1412.

Joseleau JP, Imai T, Kuroda K \& Ruel K. 2004. Detection in situ and characterization of lignin in the G-layer of tension wood fibres of Populus deltoides. Planta 219: 338-345.

Kim JS, Awano T, Yoshinaga A \& Takabe K. 2011. Occurrence of xylan and mannan polysaccharides and their spatial relationship with other cell wall components in differentiating compression wood tracheids of Cryptomeria japonica. Planta 233: 721-735.

Kim JS \& Daniel G. 2012. Distribution of glucomannans and xylans in poplar xylem and their changes under tension stress. Planta 236: 35-50.

Kim JS, Gao J, Terziev N, Allegretti O \& Daniel G. 2015. Chemical and ultrastructural changes of ash wood thermally modified (TMW) using the thermo-vacuum process: II. Immunocytochemical study of the distribution of noncellulosic polysaccharides. Holzforschung 69: $615-625$.

Kim JS, Sandquist D, Sundberg B \& Daniel G. 2012. Spatial and temporal variability of xylan distribution in differentiating secondary xylem of hybrid aspen. Planta 235: 1315-1330.

Kiyoto S, Yoshinaga A, Tanaka N, Wada M, Kamitakahara H \& Takabe K. 2013. Immunolocalization of 8-5' and 8-8' linked structures of lignin in cell walls of Chamaecyparis obtusa using monoclonal antibodies. Planta 237: 705-715.

Marcus S, Blake AW, Benians TAS, Lee KJD, Poyser C, Donaldson L, Leroux O, Rogowski A, Petersen HL, Boraston A, Gilbert HJ, Willats WGT \& Knox JP. 2010. Restricted access of proteins to mannan polysaccharides in intact plant cell walls. Plant J. 64: 191-203.

Marcus SE, Verhertbruggen Y, Hervè C, Ordaz-Ortiz J, Farkas V, Pedersen HL, Willats WGT \& Knox JP. 2008. Pectic homogalactronan masks abundant sets of xyloglucan epitopes in plant cell walls. BMC Plant Biol. 8: 60.

McCartney L, Marcus SE \& Knox JP. 2005. Monoclonal antibodies to plant cell wall xylans and arabinoxylans. J. Histochem. Cytochem. 53: 543-546.

Meyer RW \& Côté WA. 1968. Formation of the protective layer and its role in tylosis development. Wood Sci. Technol. 2: 84-94.

Murmanis L. 1975. Formation of tyloses in felled Quercus rubra L. Wood Sci. Technol. 9: $3-14$.

Musha Y \& Goring DAI. 1975. Distribution of syringyl and guaiacyl moieties in hardwoods as indicated by ultraviolet microscopy. Wood Sci. Technol. 9: 45-58.

Nakagawa K, Yoshinaga A \& Takabe K. 2012. Anatomy and lignin distribution in reaction phloem fibres of several Japanese hardwoods. Ann. Bot. 110: 897-904.

Pettersen RC. 1984. The chemical composition of wood. In: Rowell R (ed.), The chemistry of solid wood: 57-127. American Chemical Society, Washington DC.

Pomar F, Merino F \& Barceló AR. 2002. O-4-Linked coniferyl and sinapyl aldehydes in lignifying cell walls are the main targets of the Wiesner (phloroglucinol- $\mathrm{HCl}$ ) reaction. Protoplasma 220: 17-28.

Rioux D, Nicole M, Simard M \& Ouellette GB. 1998. Immunocytochemical evidence that secretion of pectin occurs during gel (gum) and tylosis formation in trees. Phytopathology 88: 494-504. 
Santos RB, Capanema EW, Balakshin MY, Chang H-M \& Jameel H. 2011. Effect of hardwoods characteristics on kraft pulping process: emphasis on lignin structure. BioResources 6: 3623-3637.

Schweingruber FH. 1990. Anatomy of European woods: an atlas for the identification of European trees, shrubs and dwaft shrubs. Paul Haupt, Bern, Stuttgart.

Scotti-Saintagne C, Mariette S, Porth I, Goicoechea PG, Barreneche T, Bodénès C, Burg K \& Kremer A. 2004. Genome scanning for interspecific differentiation between two closely related oak species [Quercus robur L. and Q. petraea (Matt.) Liebl.]. Genetics 168: $1615-1626$.

Shchupakivskyy R, Clauder L, Linke N \& Pfriem A. 2014. Application of high-frequency densitometry to detect changes in early- and latewood density of oak (Quercus robur L.) due to thermal modification. Eur. J. Wood Prod. 75: 5-10.

Taylor AM, Gartner BL \& Morrell JJ. 2002. Heartwood formation and natural durability a review. Wood Fiber Sci. 34: 587-611.

Verhertbruggen Y, Marcus SE, Haeger A, Ordaz-Ortiz JJ \& Knox JP. 2009. An extended set of monoclonal antibodies to pectic homogalacturonan. Carbohydr. Res. 344: 1858-1862.

Wheeler EA. 2011. InsideWood - a web resource for hardwood anatomy. IAWA J. 32:199-212.

Willats WGT, Marcus SE \& Knox JP. 1998. Generation of monoclonal antibody specific to $(1 \rightarrow 5)-\alpha$-L-arabinan. Carbohydr. Res. 308: 149-152.

Yoshinaga A, Fujita M \& Saiki H. 1993. Compositions of lignin building units and neutral sugars in oak xylem tissue. Mokuzai Gakkaishi 39: 621-627.

Accepted: 17 February 2016

Associate Editor: Lloyd A. Donaldson 